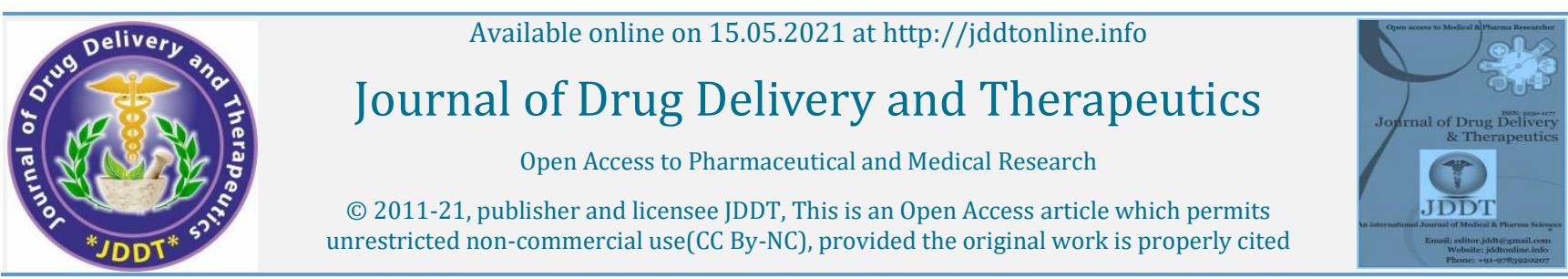

(C) 2011-21, publisher and licensee JDDT, This is an Open Access article which permits Open Access Full Text Article

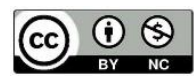

Review Article

\title{
A Review on Woodfordia fruticosa Kurz (Dhatki): Ayurvedic, Folk and Modern Uses
}

\author{
Thakur Shifali, DKaurav Hemlata, (DChaudhary Gitika* \\ Shuddhi Ayurveda, Jeena Sikho Lifecare Pvt. Ltd. Zirakpur Punjab 140603, India
}

\begin{tabular}{|c|c|}
\hline \multicolumn{2}{|l|}{ Article Info: } \\
\hline 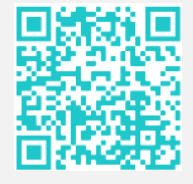 & $\begin{array}{l}\text { Article History: } \\
\text { Received 23 March 2021; } \\
\text { Review Completed 21 April } 2021 \\
\text { Accepted } 30 \text { April 2021; } \\
\text { Available online } 15 \text { May } 2021\end{array}$ \\
\hline \multicolumn{2}{|c|}{ Cite this article as: } \\
\hline \multicolumn{2}{|c|}{$\begin{array}{l}\text { Thakur S, Kaurav H, Chaudhary G, A Review on } \\
\text { Woodfordia fruticosa Kurz (Dhatki): Ayurvedic, Folk } \\
\text { and Modern Uses, Journal of Drug Delivery and } \\
\text { Therapeutics. } 2021 ; 11(3): 126-131 \\
\text { DOI: http://dx.doi.org/10.22270/jddt.v11i3.4839 }\end{array}$} \\
\hline \multicolumn{2}{|c|}{ *Address for Correspondence: } \\
\hline $\begin{array}{l}\text { Chaudhary Gitika } \\
\text { Lifecare Pvt. Ltd. } \\
\text { ORCID ID: https:/ }\end{array}$ & $\begin{array}{l}\text { Shuddhi Ayurveda, Jeena Sikho } \\
\text { Zirakpur Punjab 140603. } \\
\text { /orcid.org/0000-0003-0687-7156 }\end{array}$ \\
\hline
\end{tabular}

\begin{abstract}
Woodfordia fruticosa kurz is an herbal plant that belongs to the family Lythraceae. This plant is widely distributed throughout the tropical and subtropical regions of India, Sri Lanka, China, Malaysia, Indonesia, Japan and Pakistan. The plant possesses a long history of medicinal use. The flowers of Woodfordia fruticosa are recorded to possess potent therapeutic values. The various phytochemicals isolated from this plant are tannins, flavonoids, anthraquinone, glycosides and polyphenols. The extract of flowers and leaves are associated with useful therapeutic activities. These phytochemical compounds have many pharmacological properties such as antimicrobial, hepatoprotective, cardioprotective, antioxidant, antiulcer, immunomodulatory, antifertility and anti-tumor. These pharmacological activities of Woodfordia fruticosa plant are also mentioned in the literature of ayurveda, yunani and other traditional systems of medicine. This review is intended to provide brief information on the plant Woodfordia fruticosa on the basis of chemical constituents, folk usage, ayurvedic usage, modern usage and its biological activities.
\end{abstract}

Keywords: Woodfordia fruticosa, antimicrobial, Ayurvedic, flavonoids, Octacosanol

\section{Introduction}

Plant-derived drugs have been utilized by the majority of the world population for many years. Herbal drugs occupy an important place in both traditional and modern medicine 1,2 . The ethnobotanical knowledge is percolating down among the tribal population, but most of this knowledge is empirical at best and lacks scientific researches 3,4. Among the various plant species utilized in folk medicine, Woodfordia fruticosa kurz has been utilized by practitioners for the treatment of bowel disorders ${ }^{5}$. All the parts of this plant exhibit therapeutic properties but flowers are majorly considered to possess great therapeutic activity. Its flowers make it a commercially important plant. There are several phytochemicals responsible for their therapeutic action. In Ayurveda, various Asavas and Aristhas were prepared from this plant. Aristhas are health tonics in nature. Aristhas have overall health-stimulating properties ${ }^{6}$. There are 18 aristhas mentioned in the Indian Ministry of Health and Family Welfare's monograph (CCRIMH, 1978) in which 17 have been found to contain Woodfordia fruticose extract.
According to the Ayurvedic practitioner Charaka and Sushruta, flowers of Woodfordia fruticosa were utilized as a sweetened decoction for the treatment of fever, haemothermia, persistent dysentery and ulcers ${ }^{7}$. According to Yogaratnakara, the flowers of Woodfordia fruticosa have been utilized as a substitute for Glycyrrhiza glabra ${ }^{8}$. A wide range of chemical compounds isolated from the Woodfordia fruticosa plant includes tannins, flavonoids, anthraquinone, glycosides and polyphenols. These chemical compounds are associated with various pharmacological activities like antimicrobial, hepatoprotective, cardioprotective, antioxidant, antiulcer, immunomodulatory, antifertility and anti-tumor 9 . Many researchers are interested to study this plant in the modern times because of its therapeutic activities. Out of 87 research papers reviewed, 79 research papers describe the ethnobotanical significance of the plant 10. The vernacular names and taxonomical classification of Woodfordia fruticosa are shown in table no. 1 and table no. 2 
Table 1: Vernacular Names of Woodfordia fruticosa

\begin{tabular}{|l|l|}
\hline Hindi & $\begin{array}{l}\text { Ban-mahendi, Dhai, Dhatki, } \\
\text { Dhatki, Dhatri, Dhaura }\end{array}$ \\
\hline Sanskrit & Agnijwala \\
\hline Kannada & $\begin{array}{l}\text { Bela, Taamra pushpin, Daathakee } \\
\text { Kusumka }\end{array}$ \\
\hline Malayalam & Tamarpushi, Tatire, Tatiripushpi \\
\hline Tamil & Dhathari-jagri, Dhattari \\
\hline Telegu & Dhaarhupushpika, Dhaathaki \\
\hline Tibetan & Dha-ta-ke, Me-togda tak ki \\
\hline Urdu & Gul dhawa \\
\hline Gujarati & Dhaavadi \\
\hline Bengali & Dhai, Dawai, Dhai phul \\
\hline Marathi & Dhalas, Dhayati, Dhadva \\
\hline Punjabi & Dhavi \\
\hline Farsi & Dhaava \\
\hline Oriya & Dhobo, Jaliko, Harwari \\
\hline Bihar & Dhai, Dawai \\
\hline Jammu and Kashmir & Thwai \\
\hline Nepali & Dhangera \\
\hline
\end{tabular}

Table 2: Taxonomical classification of Woodfordia fruticosa

\begin{tabular}{|l|l|}
\hline Taxonomical Rank & Taxon \\
\hline Kingdom & Plantae \\
\hline Division & Magnoliophyta \\
\hline Class & Magnoliopsida \\
\hline Order & Myrtales \\
\hline Family & Lytheraceae \\
\hline Genus & Woodfordia \\
\hline Species & fruticosa \\
\hline
\end{tabular}

\section{Botanical Description of Woodfordia fruticosa}

Woodfordia fruticose kurz (Figure 1) belongs to the Lythraceae family. A fully-grown leafy shrub is long up to $3.5 \mathrm{~m}$ and having long and spreading branches with fluted stems. The bark is smooth and characteristically cinnamonbrown in color, peels off in fibers, the young shoots and terete, often clothed with fine white pubescence. The leaves are opposite or sub-opposite. Flowers are bright red, innumerable, arranged in dense axillary paniculate-cymose clusters, with short glandular pubescent pedicles. The calyx is striated, long, covered with glandular dots, with a small bell-like base and slightly curved with the bright red tube that contracts above the included capsule. The petals are slightly longer than calyx-teeth. Petals are extended at the apex to a long fine point. The fruits are small capsules, ellipsoid and membranous. Fruits are usually irregular dehiscent and splitting the calyx nearthe base. The seeds are brown, numerous, smooth, shining, angular and obovate 1113 .

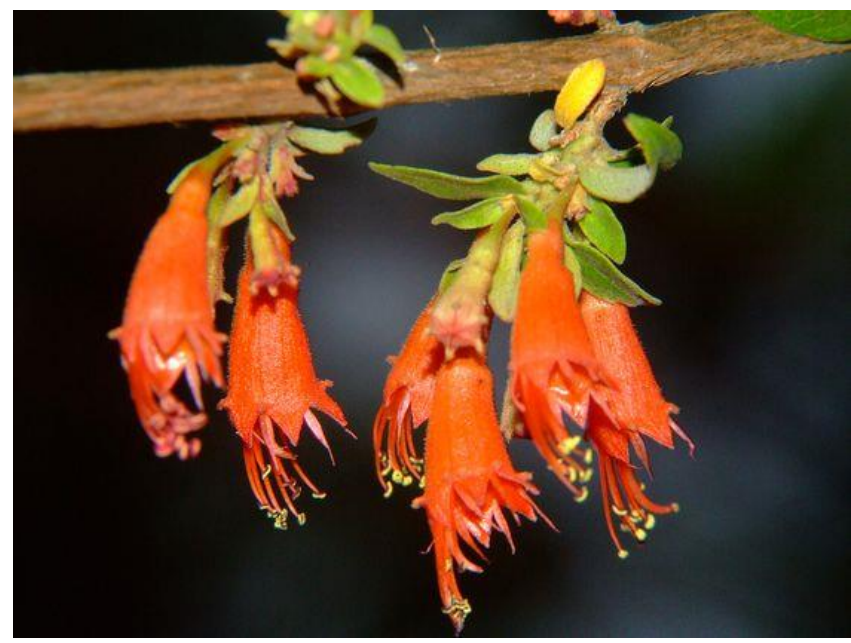

Figure 1: Woodfordia fruticosa (Dhatki Pushap)

\section{Geographical distribution of Woodfordia fruticosa}

Woodfordia fruticosa is widely distributed throughout India, Sri Lanka, China, Malaysia, Indonesia, Japan and Pakistan. In North-eastern India, it is found in Tenga and Salari to Nafra areas of East kameng district, Kawlkuth areas in Mizoram and limited northern part of West Bengal adjacent to South Sikkim district of Sikkim. It is also found in Gangetic plains 14 .

\section{Phytochemical constituents of Woodfordia fruticosa}

The chemical constituents found in Woodfordia fruticosa are mainly phenolics, hydrolyzable tannins and flavonoids. Desai et al., first examined the presence of octacosanol and $\beta$ sitosterol in the stems of Woodfordia fruticosa ${ }^{15}$. These compounds were also isolated from the flowers whereas $\beta$ sitosterol detected even in the leaves of Woodfordia fruticosa 16,17. Chauhan et al., demonstrated that flowers of this plant also contain other non-phenolic constituents like steroid sapogenin hecogenin and mesi-inositol. Dan et al., reported that the leaves of Woodfordia fruticosa contain other compounds like triterpenoids lupeol (2a), betulin (2b), betulinic acid (2c), oleanolic acid (3a) and ursolic acid (3b) 18. Apart from flavonoids or tannins, the phenolic constituents and gallic acids are also isolated from this plant. Ellagic acid is found in the leaves and flowers of Woodfordia fruticosa ${ }^{19}$. The new constituent, norbergenin is isolated from the stems, chrysophanol-8-0--glucopyranoside from flowers, and the naphthoquinone pigment lawsone from leaves of the plant Woodfordia fruticosa ${ }^{20}$. The flavonoid constituents are characterized by various groups that include six quercetin glycosides [3-rhamnoside from flowers, 3- $\beta$-L-arabinoside from flowers and leaves and 30 - $\alpha$-D-xylopyranoside,3-0- $\alpha$-L-arabinopyranoside, 3-0- $\beta$-Dxylopyranoside, 3-0-(6" - galloyl)- $\beta$-D-glucopyranoside, and 3-0-(6"-galloyl)- $\beta$-D-galactopyranoside from leaves. Three myricetin glycosides were isolated from the plant. 30 - $\beta$-D-galactoside present in flowers and leaves, $3-0-\alpha-\mathrm{L}-$ arabinopyranoside, 3-0-(6"-galloyl) $\beta$-D-galactopyranoside in leaves and naringenin 7- glucoside and kaempferol 3-0glucoside in flowers. Nair et al., examined the flowers for the orange-red pigment that lead to the identification of pelargonidin 3,5-diglucoside. The new and known hydrolysable tannins have been isolated from the flowers of Woodfordia fruticosa ${ }^{21}$. The known tannins isolated are 1,2,3,6-tetra-0-galloyl- $\beta$ - D-glucose, 1,2,4,6-tetra-0-galloyl$\beta$-D-glucose, $1,2,3,4,5$-penta-O, galloyl- $\beta$-D-glucose, tellimagrandin, gemin $\mathrm{D}$, heterophyllin $\mathrm{A}$ and oenothein $\mathrm{B} 22$. 
Some novel constituents isolated from this plant are woodfordins A-C, woodfordin D, oenothein A, isoschimawalin A and woodfordins E-I. Woodfructicosin is the new hydro sable tannins found in the leaves of this plant. The structures of some major phytochemicals of Woodfordia fruticosa are shown in figure no. 2
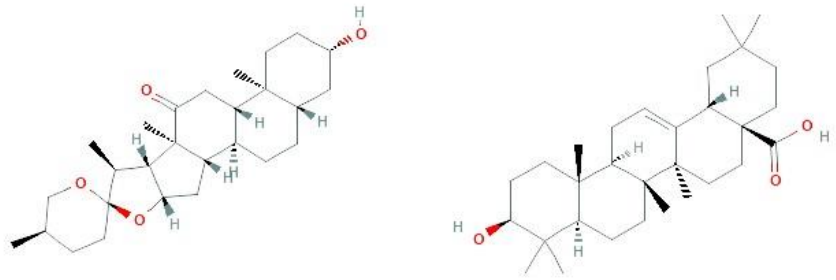

A. Hecogenin

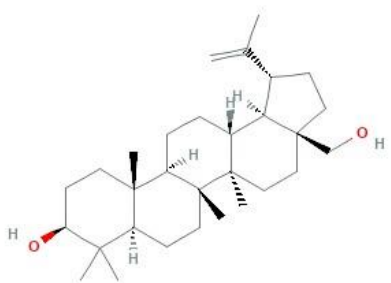

E. Betulin
B. Oleanolic Acid

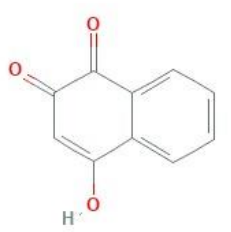

F. lawsone

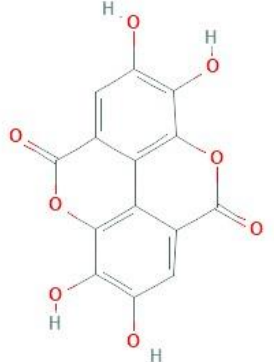

C. Ellagic Acid

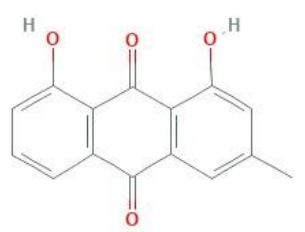

G. Chrysophanol

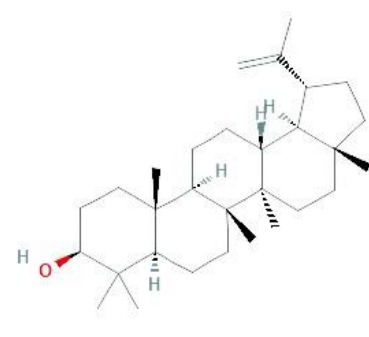

D. Lupeol

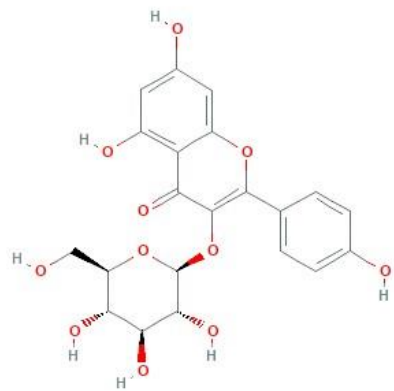

H. kaempferol_3-O-glucoside

Figure 2: The structure of major phytochemicals of Woodfordia fruticosa

\section{Traditional and Modern View}

A. Ayurvedic View: Woodfordia fruticosa is also known as Dhatki and Fire flame bush. Dhatki plant was utilized in many ayurvedic formulations by traditional practitioners 23,24. Although, all parts of the Dhatki plant possess valuable therapeutic properties but flowers are considered as a potent part because of their high demand in domestic and international markets for the preparation of herbal medicines ${ }^{25}$. According to the ayurvedic literature, Dhatki is a pungent, acrid, toxic, alexiteric, uterine sedative, and anthelmintic. It is also useful in thirst, dysentery, leprosy, erysipelas, blood diseases, leucorrhoea and toothache. Dhatki is considered as Kapha and Pitta suppressant according to the Ayurveda ${ }^{26}$. Dhatki pushpa are utilized in the formulation of herbal medicine. The medicine is called "Aristha's" and "Asava's" 27. Aristha's are known to be general health tonics which stimulates overall health with specific emphasis on ameliorating or delaying one or the other systematic disorder. There are 18 Aristha's mentioned in the Indian Ministry of Health \& Family Welfare's monograph in which 17 are found to have Woodfordia frutica extract. These herbal medicines are very popular in India and some other South Asian countries 28,29. Dhatki Pushpa are also utilized as a principal ingredient in the preparation of a popular herbal medicine "Sidowaya" or "Sidawayah" 30. Due to astringent taste, Dhatki pushpa has been utilized to treat dysentery, sprue, bowel syndrome, rheumatism, dysuria and hematuria 31.
Table 3: Rasa Panchak of Woodfordia fruticosa (Dhatki Pushpa)

\begin{tabular}{|l|l|}
\hline Sanskrit/English & Sanskrit/English \\
\hline Rasa/Taste & Kashaya/Astringent \\
\hline Virya/Potency & Sheeth/Cold \\
\hline Vipaka/Metabolic Property & Katu/Bitter \\
\hline Guna/Physical Property & Laghu,Ruksh/Little,Dry \\
\hline
\end{tabular}

Some major benefits of Woodfordia fruticosa (Dhatki) Plant

Atisara: Very effective herb for the treatment of dysentery and diarrhoea

Pittasra: The plant is used in treating bleeding disorders.

Krimighana: It is helpful against infection and parasites.

Trushna: The herb possesses cooling property and is beneficial in excessive thirst.

Visarpa: The herb protects the skin and beneficial in skin related disorders and herpes, etc.

Visha: Also helpful in toxic conditions.

B. Folk View: Woodfordia fruticosa plant is utilized many years ago in the Ayurvedic and folklore medicinal system for its therapeutic activities. The fresh flowers of Woodfordia fruticosa were used to stop bleeding in emergency cuts by the tribal people of the Chhattisgarh district. They were also preferring dried flower powder on the cuts to heal them more efficiently. Oil-based flower extract has always been 
recommended for open wounds. In case of a complicated wound, the flowers of Woodfordia fruticosa are mixed with another herb called Lodh (Symplocos crataegoides) in equal quantity and utilized among these tribes. A decoction of fresh flowers in combination with ginger (Zingiber officinale) or intrajua (Wrightia tinctoria) is utilized for the treatment of dysentery. Woodfordia fruticosa plant was utilized for the management of female-specific disorders like leucorrhoea and dysmenorrhoea among these tribes. The Woodfordia fruticosa plant was majorly used by various communities in India and these tribes are Gopala (Keonjhar district), kandha and Brahmin (Koraput district), Kandha, Dhoba and Kshatriya (Kandhamal District), Sabar (Baragarh district), Santal (Mayurbhanj district) and Sundhi (Malkangiri district). In Nepal and India, leaves of Woodfordia fruticosa are used as folk medicine to treat variety of diseases. A decoction of plant leaves in combination with sugar and dried ginger is recommended for the treatment of fever 32 .

C. Modern View: Many issues are faced by the Global herbal drug industry in today's scenario mostly the practice of making these drugs adulterated. This is the major reason why people lost faith in these herbal drugs nowadays $33-37$. In today's time, intentional adulteration is practiced in many different ways like by substituting standard commercial variety, by substituting superficially similar but inferior drugs, by substituting artificially manufactured drugs, the substitution of exhausted drugs and by substituting toxic materials. Adulteration can be either intentional or unintentional. These adulteration processes ultimately degrade the quality of the original drugs. The herbal plant vendors use these adulteration techniques so smartly that these remain undetectable until and unless examination on a microscopic level and chemical level are implied 38-40. The major disadvantages associated with adulteration are deterioration and degradation of drugs. Adulteration also increases the cost of drugs and produces adverse effects instead of showing actual biological affect 41,42. The traditional herbal drugs and their formulations are associated with negligible toxicity and are free from any kind of adulteration ${ }^{43}$. Herbal plants have a very important place in both commercial industry and pharmaceutical industries. Ranganayaki and Ranganathan investigated the use of leaves and flowers of Woodfordia fruticosa for the production of tan-extract in fine tanning of soft leather 44 . Dastur et al., reported that the flowers are being used for the production of red dyes throughout India 45 . These all are commercial uses but this plant is also extensively used in the modern medication system. Traditional Ayurvedic herbal formulations of Woodfordia fruticosa plants are associated with a wide range of medicinal properties that cures a variety of ailments without causing any severe harm to the human body. Oshima et al., reported a polyherbal formulation containing for the prevention and treatment of dental plaque formation ${ }^{46}$. Several researches are going on the Woodfordia fruticosa flowers and leaves in the form of ointment for skin whitening 47-50. Some of the cosmetic formulations were claimed to be capable of reducing the activity of hyaluronidase, elastase, and tyrosinase. Thus plant is found to be effective against skin roughness too.

\section{Reported Therapeutic and Pharmacological Studies of Woodfordia fruticosa}

Various researches have been conducted on this plant to find out its therapeutic and pharmacological uses. Large -scale scientific studies are still needed to prove the clinical efficacy of this herb, especially in skin diseases, immunomodulatory disorders and diabetes.
Antimicrobial Activity: Kumaraswamy et al., reported antimicrobial activity of dried flower extracts of Woodfordia fruticosa. The ethanol, methanol, petroleum ether, chloroform and water were used for extracting dried flowers. Out of these five extracts, petroleum ether extract showed significant antimicrobial activity when compared to Gentamicin (standard drug). Another In-vivo study showed antibacterial activity of crude methanolic extract of Woodfordia fruticosa when compared with the standard drug ciprofloxacin using the agar well diffusion method. Methanolic extract was found be most active against Pseudomonas pseudoalcaligenes 51 . Another study examined the antibacterial activity of diethyl ether, chloroform, petroleum ether extract against four bacterial species strains by using disc diffusion method. The extracts were found to be effective against all the strains ${ }^{52,53}$.

Immunomodulatory Activity: Shah et al., reported immunomodulatory activity of ethanolic extract of the flowers of Woodfordia fruticosa. In-vitro immunomodulatory activity of the extract was evaluated in murine peritoneal macrophage phagocytosis and proliferation of bone marrow cells by sulforhodamine 'B' (SRB) assays. Results showed $60 \%$ increase in bone marrow cell proliferation and represents the stimulation of bone marrow 54 .

Hepatoprotective Activity: Brinda et al., reported hepatoprotective activity of petroleum ether, alcohol, chloroform and aqueous extract of flower of Woodfordia fruticosa against phenytoin induced rats and carbon tetrachloride-induced toxicity ${ }^{55}$. Baravaia et al., reported hepatoprotective activity of methanolic extract of the flowers of Woodfordia fruticosa against acetaminophen-induced rats and diclofenac sodium-induced rats 56 . Both studies demonstrated the hepatoprotective activity of the Woodfordia fruticosa plant for the treatment of liver disorders.

Cardioprotective Activity: Lal et al., reported an Ayurvedic formulation for cardiovascular disorders. A decoction was prepared by fermenting the specific plant materials using flowers of Woodfordia fruticosa. The formulation was named as "Arjunaristha" which was beneficial for cardiac disorders 57.

Antioxidant Activity: Finose et al., evaluated the antioxidant activity of Woodfordia fruticosa flowers by using ABT and DPPH free radical scavenging models. The petroleum ether, chloroform and methanol extracts of the plant showed significant antioxidant activity in results 58 .

Antiulcer Activity: Mihira et al., reported antiulcer activity of chloroform and methanol extract of roots of Woodfordia fruticosa against diclofenac sodium-induced female Wister albino rats. The result showed significant antiulcer activity in the stomach of female Wister albino rats 59 .

Antifertility Activity: Kushlani et al., reported antifertility activity of various extract of dried flowers of Woodfordia fruticosa in female albino rats. The results revealed that the alcoholic extract of the plant showed significant abortifacient activity 60

Anti-tumor Activity: Yoshida et al., reported anti-tumor activity of dried flower extract of Woodfordia fruticosa plant. Woodfordin C, a macro ring hydrolysable tannin dimer was found to possess anti-tumor activity 61 .

Analgesic Activity: Rose et al., evaluated the analgesic activity of Woodfordia fruticosa stem bark in albino rats. The petroleum ether, chloroform, ethanol and aqueous extracts were administered orally to the rats at a dose of $200 \mathrm{mg} / \mathrm{kg}$ according to their body weight. The standard group was 
administered with Analgin (non-steroidal anti-inflammatory drugs). The aqueous and alcoholic extracts were found to possess analgesic activity in albino rats. It was also found that the aqueous extract showed most potent analgesic effect as compared to petroleum ether and alcoholic extract 62 .

Antihyperlipidemic activity: Khera et al., reported antihyperlipidemic activity of methanolic flower extract of Woodfordia fruticosa in mice with a high cholesterol diet. Five groups of six Swiss albino mice were administered with $0.5 \mathrm{ml}$ water, $30 \mathrm{mg}$ cholesterol and $400 \mathrm{mg} / \mathrm{kg}$ of methanolic extract of Woodfordia fruticosa flowers. The effects of the extract on the lipid profile showed lipid-lowering effect. Woodfordia fruticosa is considered as new potential natural product for controlling hyperlipidemia 63 .

Anti-inflammatory Activity: Baravalia et al., reported antiinflammatory activity of methanol extract of Woodfordia fruticosa flowers against the carrageenan, histamine, dextran, serotonin and formaldehyde-induced rats. The result showed significant anti-inflammatory activity in the animal model 64 .

Antihyperglycemic Activity: Verma et al., reported the antihyperglycemic activity of flower extract of Woodfordia fruticosa in glucose metabolism and lipid peroxidation in streptozotocin-induced diabetic rats. After 21 days of treatment, it was found that the ethanolic extract of Woodfordia fruticosa significantly reduced the fasting blood glucose level and increases the insulin level in diabetic rats. The results suggested that ethanolic flower extract possesses a potent antihyperglycemic effect 65 .

Anthelmintic Activity: Sengupta et al., examined the anthelmintic activity of methanol and petroleum ether extract of dried flowers of Woodfordia fruticosa against the Indian earthworm like Pheritima Posthuma 66.

\section{Conclusion:}

Woodfordia fruticosa is a popular therapeutic plant useful in various disorders since past times. It is utilized as an ointment in various regions of the world especially in India and Nepal. Woodfordia fruticosa plant is a rich storehouse of chemical constituents like Oenothein A, Woodfordin C, Woodforin F, Isoschimawalin A and many others. Various preparation containing Woodfordia fruticosa along with several other medicinal plants. These formulations are prescribed by the traditional medical practitioners to treat numerous disease. From reported studies, it is clear that the Woodfordia fruticosa plant contains various chemical constituents and they play a vital role in the pharmaceutical and industrial application to produce modern herbal formulations. Aristha's or Asava's are the main herbal formulation containing flowers of $W$. fruticosa. But there is a need to relook and revaluate these formulations scientifically. Besides this, the plant is associated with various therapeutic and medicinal properties like antioxidant, antidiabetic, hypertensive, antifungal, antibacterial, anti-tumor, antiviral, antispasmodic and many more.

\section{Acknowledgement}

Authors are very thankful to the Department of Research and Development of Jeena Sikho Lifecare Pvt. Ltd. Zirakpur, Punjab for giving us opportimity to explore this ancient medicinal plant.

\section{Conflict of Interest}

None

\section{References}

1. Nature AO. s medicinal bounty: don't throw it away. In world Health Forum. 1993; 14:390-395.

2. Baker DD, Alvi KA. Small-molecule natural products: new structures, new activities. Current opinion in biotechnology. 2004 Dec1; 15(6):576-83.

3. Houghton PJ. The role of plants in traditional medicine and current therapy. The Journal of Alternative and Complementary Medicine. 1995 Jun 1; 1(2):131-43.

4. Fong HH. Integration of herbal medicine into modern medical practices: issues and prospects. Integrative cancer therapies. 2002 Sep; 1(3):287-93.

5. Shome U, Mehrotra S, Sharma HP. Pharmacognostic studies on the flower of Woodfordia fruticosa Kurz. Proceedings: Plant Sciences. 1981 Aug 1; 90(4):335-51.

6. Thakur RS, Puri HS, Husain A. Major medicinal plants of India. Lucknow, India: Central Institute of Medicinal and Aromatic Plants; 1989.

7. Khare C.P. Encyclopedia of Indian Medicinal Plants. SpringerVerlag Berlin Heidelberg; 2007. pp. 483-484.

8. Saxena N. Yogaratnakara - An important source book in medicine. Indian Journal of History of Science. 1992; 27(1):1528.

9. Shandesh B, Dinesh RB. Medicinal Usefulness of Woodfordia fruticosa (Linn.) Kurz. Ethnomedicinal Plants: Revitalizing of Traditional Knowledge of Herbs. Science Publishers. 2011:25368.

10. Shanker R, Rawat MS. Exploration, conservation and cultivation of Woodfordia fruticosa kurz in north east India. Intern J Med Plnt. Photon. 2013; 105:213-217.

11. Kirtikar, K.R., Basu, B.D. Indian Medicinal Plants. Allahabad: Lalit Mohan Publication; 1935.

12. Shome U, Mehrotra S, Sharma HP. Pharmacognostic studies on the flower ofWoodfordia fruticosa Kurz. Proceedings: Plant Sciences. 1981 Aug 1; 90(4):335-51.

13. Khare CP. Indian herbal remedies: rational Western therapy, ayurvedic, and other traditional usage, Botany. Springer, Berlin, Heidelberg; 2004.

14. Syed YH, Khan M, Bhuvaneshwari J, Ansari JA. Phytochemical investigation and standardization of extracts of flowers of Woodfordia fruticosa; a preliminary study. J Pharm Biosci. 2013; 1:134-40.

15. Anjaneyulu B, Babu Rao V, Ganguly AK, Govindachari TR, Joshi BS, KamaY VN, Manmade AH, Mohamed PA, Rahimtula AD, Saksena AK, Varde DS. Chemical investigation of some Indian plants. Indian Journal of Chemistry. 1965; 3(5):237-8.

16. Chauhan, J.S., Srivastava, S.K., Srivastava, S.D. Phytochemical investigation of the flowers of Woodfordia fruticosa. Planta Medica.1979; 36(2):183-184

17. Dan S, Dan SS. Chemical examination of the leaves of Woodfordia fruticosa. J Indian Chem Soc. 1984 Jan 1; 61:726-7.

18. Chauhan, J.S., Srivastava, S.K., Srivastava, S.D. Chemical constituents of Woodfordia fruticosa Linn. Journal of the Indian chemical society. 1979; 56(10):1041

19. kalidhar sb, parthasarathy mr, sharma p. Norbergenin, A New CGlycoside from Woodfordia-fruticosa Kurz. Indian Journal of Chemistry Section b-Organic Chemistry Including Medicinal Chemistry. 1981 Jan 1; 20 (8):720-1.

20. Kadota S, Takamori Y, Nyein KN, Kikuchi T, Tanaka K, Ekimoto H. Constituents of the leaves of Woodfordia fruticosa KURZ. I: Isolation, structure, and proton and carbon-13 nuclear magnetic resonance signal assignments of Woodfruticosin (Woodfordin C), an inhibitor of deoxyribonucleic acid topoisomerase II. Chemical and pharmaceutical Bulletin. 1990 Oct 25; 38(10):2687-97.

21. Nair, A.G.R., Kotiyal, J.P., Ramesh, P., Subramanian, S.S. Polyphenols of the flowers and leaves of Woodfordia fruticosa. Indian Journal of Pharmacy. 1976; 38:110-111.

22. Saoji AG, Saoji AN, Deshmukh VK. Presence of Lawsone in Ammania bacciferra Linn. and Woodfordia fruticosa Salisb. Current Science. 1972 Mar 5; 41(5):192-.

23. Chopra, R.N., Nayar, S.L., Chopra, I.C. Glossary of Indian Medicinal Plants. New Delhi: CSIR; 1956

24. Watt, G. A Dictionary of Economic Products of India. III. Periodical Expert. Delhi: Cosmo Publications; 1972.

25. Oudhia, P. Interaction with the Herb Collectors of Gandai Region, Chhatisgarh, MP, India. 2003. 
26. Sharma, P.V. Dravyagun Vigyan. Varanasi: Chaukambha Bharti Academy; 1956.

27. Atal CK, Bhatia AK, Singh RP. Role of Woodfordia fruticosa Kurz (Dhataki) in the preparation of Asavas and Arishtas. J Res Ayurved Sidd. 1982; 3:193-9.

28. Jayaweera, D.M.A. Medicinal Plants used in Ceylon. Part III. Colombo: The National Science Council of Sri Lanka; 1981. p. 289.

29. Kroes BH, Van den Berg AJ, De Silva KT, Labadie RP. Investigation on Nimba Arishta, an immunomodulating ayurvedic drug obtained by Fermentation. Journal of European Ayurvedic Society. 1992; 2:123-33.

30. Burkill, I.H. A Dictionary of Economic Products of the Malay Peninsula. Malaysia: Ministry of Agriculture and Co-operatives, Kuala Lumpur;1966. p. 2305.

31. Dey KL. The Indigenous Drugs of India. Dehradun: International Book Distributors; 1984.

32. Das PK, Goswami S, Chinniah A, Panda N, Banerjee S, Sahu NP, Achari B. Woodfordia fruticosa: Traditional uses and recent findings. Journal of Ethnopharmacology. 2007 Mar 21; 110(2):189-99.

33. Tewari NN. Some crude drugs: source, substitute and adulterant with special reference to KTM crude drug market. Sachitra Ayurved. 1991; 44(4):284-90.

34. Shukla P, Pawar RM. OA01. 22. Quality aspect and variability observed in physico-chemical characteristics and minera content of ayurvedic herbo mineral formulations from Indian market. Ancient Science of Life. 2012 Dec; 32(Suppl 1):S22.

35. Sunita G. Substitute and adulterant plants. Substitute and adulterant plants. New Delhi: CSIR; 1992.

36. Uniyal MR, Joshi GC. Historical view of the basic principles of the identification of controversial drugs, problems and suggestions. Sachitra Ayurved. 1993; 45(7):531-6.

37. Saraswathy A. Adulterants and substitutes in Ayurveda. Sachitra Ayurved. 2001; 54(1):63-6.

38. Monika, Kaushal K. Adulteration in Ayurvedic Raw Herbs. International Journal of Science and Research. 2017; 6(9): 1530 $-1533$.

39. Afaq SH. A comparative introduction of the Unani and Tibetan medical traditions. Ayur Vijnana. 1999; 6:1-4.

40. Mitra SK, Kannan R. A note on unintentional adulterations in Ayurvedic herbs. Ethnobotanical Leaflets. 2007; 2007(1):3

41. More DB, Giradkar PS. Herbal Drug Adulteration: A Hindrance to the Development of Ayurveda Medicine. International Journal of Ayurvedic and Herbal Medicine. 2020; 10(2): 3764-3770.

42. Thakur S, Kaurav H, Chaudhary G. Terminalia arjuna: A Potential Ayurvedic Cardio Tonic. International Journal for Research in Applied Sciences and Biotechnology. 2021 Apr 16; 8(2):227-36.

43. Gupta V, Sharma M. Protective effect of Cinnamomum tejpata on lipid peroxide formation in isolated rat liver homogenate. Curr Res J Biol Sci. 2010 Jul 20; 2:246-9.

44. Ranganayaki MD, Ranganathan TS. Indigenous Indian tanning materials. Woodfordia fruticosa. 1966; 13:293-7.

45. Dastur, J.F. Medicinal Plants of India and Pakistan. Mumbai: Taraporevala Sons \& Co. Ltd; 1951.

46. Oshima, K., Mitsunaga, T. Glucosyltransferase inhibitor. Japanese Patent. 1999; 11:343,247.

47. Nanba, T., Hattori, Y., Shimomura, K., Takamatsu, S. Cosmetic Japanese Patent. 1995; 7:126-144.

48. Ueda, K., Shimomura, K. Cosmetic. Japanese Patent. 1995; 7:157420.
49. Suzuki, R., Umishio, K., Hasegawa, K., Moro, O. External preparation for skin. Japanese Patent. 2004. 2,004,352,658.

50. Adachi K, Tada T, Aramaki K. Elastase inhibitors or Maillard reaction inhibitors for antiwrinkle cosmetics. Japanese Patent 2006; 2(006):062-989.

51. Kumaraswamy MV, Kavitha HU, Satish S. Antibacterial potential of extracts of Woodfordia fruticosa Kurz. on human pathogens. World J Med Sci. 2008; 3(2):93-6.

52. Parekh J, Chanda S. In vitro antibacterial activity of the crude methanol extract of Woodfordia fruticosa Kurz. Flower (Lythraceae). Brazilian Journal of Microbiology. 2007 Jun; 38(2):204-7.

53. Chougale AD, Padul MV, Arfeen S, Kakad Sl. Antibacterial activity directed fractionation of Woodfordia fruticosa kurz. leaves. Journal Medicinal Plants. 2009; 8(31):75-81.

54. Shah AS, Juvekar AR. In vitro and in vivo immunostimulatory activity of Woodfordia fruticosa flowers on non-specific immunity. Pharmaceutical biology. 2010 Sep 1; 48(9):1066-72.

55. Brindha D, Geetha R. Evaluation of the protective efficacy of Woodfordia fruticosa on phenytoin induced liver damage in rats. Journal of cell and tissue research. 2009 Dec 1; 9(3):1981.

56. Baravalia Y, Vaghasiya Y, Chanda S. Hepatoprotective effect of Woodfordia fruticosa Kurz flowers on diclofenac sodium induced liver toxicity in rats. Asian Pacific Journal of Tropical Medicine. 2011 May 1; 4(5):342-6.

57. Lal UR, Tripathi SM, Jachak SM, Bhutani KK, Singh IP. HPLC analysis and standardization of Arjunarishta-an Ayurvedic Cardioprotective formulation. Scientia Pharmaceutica. 2009 Sep; 77(3):605-16.

58. Finose A, Devaki K. Phytochemical and Chromatographic Studies in the Flowers of Woodfordia fruticosa $(L)$ kurz. Asian Journal of Plant Science and Research 2011; 1(3):81-85.

59. Mihira V, Ramana KV, Ramakrishna S, Rambabu P. Evaluation of anti-ulcer activity of Woodfordia fruticosa roots. Pharmanest. 2011;2(2-3):158-60.

60. Kushlani H, Tatke P, Singh KK. Antifertility activity of dried flowers of Woodfordia fruticosa Kurz. Indian Journal of Pharmaceutical Sciences. 2006; 68:512-529.

61. Yoshida T, Chou T, Haba K, Okama Y, Shingu T, Miyamoto K et al macro cyclic ellagitanin dimmers and related dimmers and their anti-tumor activity. Chemical and Pharmaceutical Bulletin 1989a; 37:3174-3176.

62. Rose BN, Prasad NK. Analgesic activity of extracts of Woodfordia fruticosa stems bark in animal models. Indian Journal of Biological and Pharmaceutical Research. 2013; 4(4):175-180.

63. Khera N, Bhatia A. Antihyperlipedemic activity of Woodfordia fruticosa extract in high cholesterol diet fed mice. Int. J. Pharm. Phytopharmacol. Res. 2012 Nov 1; 2:211-5.

64. Baravalia Y, Kumar YV, Chanda S. Brine shrimp cytotoxicity, antiinflammatory and analgesic properties of Woodfordia fruticosa kurz flowers. Iran J Pharm Res. 2012; 11:854-861.

65. Verma N, Amresh G, Sahu PK, Rao V, Singh AP. Antihyperglycemic activity of Woodfordia fruticosa Kurz flowers extracts in glucose metabolism and lipid peroxidation in streptozotocin induced diabetic rats. Indian Journal of Experimental Biology. 2012; 50:351- 358.

66. Sengupta R, Rofel, Bilakhia GM. Comparative in-vitro anthelmintic and phytochemical evaluation of methanolic and petroleum ether extracts of Woodfordia fruticosa flowers. International Research Journal of Pharmacy. 2013; 4:159-161. 